\title{
A Meta-Model of Inter-Organisational Cooperation for the Transition to a Circular Economy
}

\author{
Alessandro Ruggieri ${ }^{1}$, Alessio Maria Braccini ${ }^{1}$, Stefano Poponi ${ }^{2, *}$ and Enrico Maria Mosconi ${ }^{1}$ \\ 1 Department of Economics and Entrepreneurship, Università degli Studi della Tuscia, via del Paradiso 47, \\ 01100 Viterbo (VT), Italy; ruggieri@unitus.it (A.R.); abraccini@unitus.it (A.M.B.); \\ enrico.mosconi@unitus.it (E.M.M.) \\ 2 Faculty of Economics, Università degli Studi Niccolò Cusano, via Don Carlo Gnocchi 3, 00166 Roma, Italy \\ * Correspondence: stefano.poponi@unicusano.it; Tel.: +39-0761-357-728
}

Academic Editor: Marc A. Rosen

Received: 15 June 2016; Accepted: 3 November 2016; Published: 10 November 2016

\begin{abstract}
The transition to a circular economy bodes well for a future of environmentally sustainable growth and economic development. The implications and advantages of a shift to a circular economy have been extensively demonstrated by the literature on the subject. What has not been sufficiently investigated is how this paradigm can be enabled through the inter-organisational cooperation among different business enterprises. In order to illustrate this point, in this paper we aim to contribute to the circular economy debate by describing and discussing such a meta-model of inter-organisational cooperation. The present study is therefore based on the analysis of three cases from an equal number of industries, from which we identified factors of potential impact for the stimulation of cooperation in a circular economy perspective. Last, but not least, we discuss the relations between the case studies and try to formulate all possible implications for both managers and research.
\end{abstract}

Keywords: circular economy; inter-organisational cooperation; sustainability; meta-model

\section{Introduction}

Sustainable development is a challenge for business organizations, which are called on to balance their rate of natural resources exploitation without compromising that of future generations $[1,2]$. Within sustainable development, the circular economy has emerged as a strategy to re-target production processes following a pattern of enhanced sustainability [3,4]. First, in a circular economy system, production is no longer a linear process, that is, produce-consume-dispose. Production is, on the contrary, circular because in it raw materials and by-products re-enter into the natural environment, or are reused in subsequent production cycles, thus reducing environmental impact and increasing the resilience of economic ecosystems [5].

The attention of the literature on the circular economy has been, so far, mostly concentrated on the differences between the linear and the circular approach [5], with a specific focus on assessing the potential environmental benefits [6,7], and the advantages for stakeholders of such a development strategy [8-10]. Literature has studied how to improve the sustainability of end-of-life products and services through their re-engineering [11-13], the adoption of assembling/disassembling practices [14], or a combination of products and services [15].

What we have found, through the study of the existing literature, is that it has extensively studied circular economy applications, but has paid less attention to the implications of cooperation among different business organizations [16-18]. Therefore, with this work we aim to contribute to the literature on the circular economy by specifically focusing on the inter-organisational cooperation perspective. Through the analysis of three case studies, from an equal number of different industries, we identify the 
factors affecting inter-organisational cooperation aimed at implementing circular economy principles. Starting from these factors we eventually describe and discuss a meta-model of the circular economy.

\section{Circular Economy}

The concept of circular economy has gained momentum after the 2012 World Economic Forum, where a report described for the first time its advantages and the path to steer economic development in that direction [3]. The idea underpinning the concept of circular economy is that of mimicking the circularity of biological processes, ensuring that nutrients and raw materials used in production processes and products could easily be recycled at the end of their lives by: (i) being reintroduced into the environment; or (ii) being reintroduced into a new production process as a secondary raw material [19]. Circular economy is, in fact, a closed-loop development model that avoids, where possible, waste [5].

An extensive application of circular economy will purportedly bring several advantages. The most intuitive and frequently cited ones are related to an increased sustainability of industries, due to the reduced dependency on natural resources [6,7], and to an increased resilience of production systems being less dependent on raw materials [20]. The single business organization implementing the strategy can expect advantages of reduction of costs, innovation opportunities, and enriched knowledge capital [8].

The literature focuses on three main aspects for a shift to a circular economy: (i) the design of products and processes [21]; (ii) the value propositions and the business models of industries and organizations [22]; and (iii) the societal acceptance of this different way of organizing and consuming products and the eventual impacts on consumers' behaviour [23].

A concrete contribution to the circularity of products and services comes from the consideration of the possibility of recycling and reusing products and by-products at the end of their lives from the time of their design [11,12,24,25], and through innovative assembling and disassembling practices [14]. From this perspective there is room for improvement, by extensively adopting the principles of the partition of technical and biological nutrients and toxicants in products and in production processes [26].

The shift to a circular economy is associated with the need of innovating business models, thanks to the systemic interaction of products and services [15], with societal innovation, and with changes in consumer behaviour [9].

Applications of a circular economy are commonly studied within the boundary of a single transformation process or business organization [13]. The organisational model most frequently discussed is that of product and service systems, where a bundle of products and services grant reuse, recycling, and circularity over a specific value chain [27]. This strategy is used to facilitate the planning of production systems with a low environmental impact, on the basis of equal economic growth [10].

The transition to a circular economy goes beyond the borders of a single organization [28], and stimulates a cooperation among different actors within a logic of the deconstruction of the value chains, and the reconstruction of new ones, over networks $[29,30]$.

\section{Research Design}

This paper aims to foster debate on the circular economy by investigating the following research question: Which factors impact on the cooperation among different business organizations for the development of circular approaches? To answer this we analysed three cases, belonging to different industries, all located in the Lazio Region, central Italy. The specific settings were chosen as revelatory cases [31] in order to be able to study the factors influencing actual or potential cooperation aimed at applying circularity principles of production among different business organizations. All the three research units are characterized by a high level of heterogeneity in terms of raw materials, competences, customers, waste, and technologies. The research units were specifically chosen to observe different industries with significant environmental impacts, without direct interdependencies, and to observe their existing 
and potential inter-organisational cooperation with other business organizations. More specifically, the case units and the specific rationale motivating their choice are:

- A firm from the industrial sector manufacturing sanitary ceramic which was included for: (i) its environmental impact, being an energy-intensive industry; (ii) the presence of a product design phase in the production process; and (iii) the location of the unit in a cluster with potential inter-organisational cooperation opportunities;

- A firm producing extra-virgin olive oil, which was included for: (i) being part of an industry that intensively consumes natural resources; and (ii) for being an industry that develops on a local, or regional scale, where several producers are active on the same territory, with a consequent potential of inter-organisational cooperation opportunities;

- A wood transformation firm, which was included for: (i) being part of an industry that produces environmental impact due to the usage of natural resources; and (ii) for the high recycling potential of the waste produced; and (iii) for the absence of structured relationships at cluster or regional level among different business organizations in the same industry.

The cases were studied to identify, discuss, and analytically generalize factors influencing the development of circular application approaches in the three units. Given our research perspective on inter-organisational cooperation, we resorted to an empirically driven research design, rather than a traditional hypothesis testing which would have been less adequate in a case where the existing literature has not explored potential relevant factors and their relationships [32-34].

In the analysis, we made use of secondary data, direct observations, and authors' previous research experiences in their specified domains. The secondary data were the main source for documenting the process. For each of the case units we were able to obtain: technical and financial reports concerning the product design and production process, the environmental impact and the related costs, and the actual cooperation with other business organizations. These information sources were complemented by observations of existing processes in the case.

In the analysis of the cases we were interested in identifying factors impacting potential applications of circular economy principles among the value chains of the specified industries, and in describing how they are interrelated. We reconstructed the production process and the environmental impact of each of the three industries in which the analysed units work. We identified the steps of the production process, the raw materials used, and the waste produced. We eventually investigated actual strategies for recycling materials and waste within the same process, or in different processes in cooperation with different business organizations. We eventually also discussed potential ways of increasing the development of circular economy applications within the industries by focusing on strategies to reduce or avoid waste, or to exploit their residual value. To this regard, we also touched upon potential inter-organisational cooperation opportunities, which are possible but currently not happening in practice, in order to identify reasons motivating their absence. The results of the analysis were discussed with domain experts in order to ensure external validity.

The factors identified, and their relations, were then confronted, abstracted from the domains of the specific industries analysed, and discussed by researchers across the cases and across the literature. They will eventually form a meta-model of the circular economy based on inter-organisational cooperation. The representation through a meta-model allows to describe the most relevant aspects of a considered domain. In a meta-model, conceptual factors, coming from implicit and explicit models, and from theoretical models, are eventually integrated into a new holistic model $[10,35,36]$.

\section{Cases Description}

\subsection{Sanitary Ceramic Industry}

The first unit of analysis is a firm of the sanitary ceramic industry. The industry shows low levels of innovativeness visible in the low technological level of products, and in the massive resort to artisan 
processes. Production shows, on average, low efficiency, high waste, and a product defect rate higher than the average of other sectors. That of sanitary ceramic is an energy-intensive industry, where costs for energy sum up to three percent of the annual turnover. The unit of analysis is a large organization, which differs slightly from this profile for a technological level higher than the average of the industry.

The production process is composed of three phases: primary, secondary, and support (see Table 1).

Table 1. Process production of sanitary ceramics.

\begin{tabular}{|c|c|c|c|c|}
\hline & Process Steps & Input & Skills and Tools & Output \\
\hline 1. & Modelling of moulds & $\begin{array}{l}\text { Plaster } \\
\text { Resin }\end{array}$ & $\begin{array}{l}\text { Model designers } \\
\text { and software }\end{array}$ & Moulds \\
\hline 2. & $\begin{array}{l}\text { Making of enamel, } \\
\text { mix and plasters }\end{array}$ & $\begin{array}{l}\text { Mineral compounds } \\
\text { Solvents } \\
\text { Chemical agents }\end{array}$ & Personnel for the mixes & Raw materials for production \\
\hline 3. & $\begin{array}{l}\text { Casting, finishing, } \\
\text { and drying }\end{array}$ & $\begin{array}{l}\text { Mineral compounds (for } \\
\text { vitreous china or fire-clay) }\end{array}$ & Personnel for the casting & $\begin{array}{l}\text { Good products } \\
\text { Non-conformant products } \\
\text { (100\% for reprocessing) }\end{array}$ \\
\hline 4. & Drying, blowing, enamelling & $\begin{array}{l}\text { Enamel } \\
\text { Products }\end{array}$ & $\begin{array}{l}\text { Personnel for enamelling } \\
\text { and finishing }\end{array}$ & $\begin{array}{l}\text { Semi-finished products } \\
\text { for baking } \\
\text { Non-conformant products } \\
(100 \% \text { for reprocessing) }\end{array}$ \\
\hline 5. & Baking & Semi-finished products & Furnace personnel & $\begin{array}{l}\text { Finished product } \\
\text { Non-conformant products } \\
\text { (light, reprocessing) } \\
\text { Non-conformant products } \\
\text { (serious, waste) }\end{array}$ \\
\hline 6. & Inspection, restoring & $\begin{array}{l}\text { Products with light } \\
\text { non-conformity }\end{array}$ & $\begin{array}{l}\text { Restorer } \\
\text { Inspector }\end{array}$ & Product for re-baking \\
\hline 7. & Blowing and re-baking & Product for re-baking & $\begin{array}{l}\text { Restorer } \\
\text { Furnace personnel }\end{array}$ & $\begin{array}{l}\text { Conformant products } \\
\text { Non-conformant products } \\
\text { (light, reparable) } \\
\text { Non-conformant products } \\
\text { (serious, waste) }\end{array}$ \\
\hline 8. & Choice adjustment & $\begin{array}{l}\text { Conformant and } \\
\text { repairable products }\end{array}$ & $\begin{array}{l}\text { Responsible for } \\
\text { the quality }\end{array}$ & Final product \\
\hline 9. & Packing and preparation & Saleable product & Warehousemen & Shipping products \\
\hline 10. & $\begin{array}{l}\text { Waste, disposal, } \\
\text { transportation support } \\
\text { industrial activities }\end{array}$ & $\begin{array}{l}\text { Non-conformant products } \\
\text { (baked ceramic product), } \\
\text { plaster, clay, water }\end{array}$ & Warehousemen & $\begin{array}{l}\text { Waste }(9.76 \% \text { on } \\
\text { total production) }\end{array}$ \\
\hline
\end{tabular}

The primary phase encompasses all the activities needed for the finalization of the product (steps 1 to 5 ). This phase is characterized by manual and highly specialized technical skills and expertise, especially for the finishing of the product (before baking). In this phase, moulds are modelled to nurture the production lines, and to create prototypes of specific products. When the prototypes are approved the process continues with the creation of the mother mould.

The secondary phase is represented by the reprocessing of the product (steps 6 to 8 ). This phase starts only if the product requires reprocessing to avoid impurities in the enamel. This phase is costly in terms of both personnel and energy use, because the product needs to be reprocessed and rebaked.

The support phase (steps 9 and 10) concerns the preparation of the product for packing, and eventual shipment, and the disposal of waste produced by the process.

Through the years, the unit we analysed underwent a product and process redesign-also making use of public financial incentives to innovate-to increase the environmental sustainability of the production (by reducing energy use, materials use, and waste), to respond to the challenges in the sector, and to deal with environmental constraints and costs. With regard to the production process, the main actions were aimed at reducing the consumption of water, and reducing the pollutants in use, specifically in plasters and clays, through the use of new materials. As regards the products, on the other hand, changes aimed at increasing quality and improving the design, the unit also performed 
changes to increase sustainability by reducing the amount of water during the life of specific products (e.g., toilet bowls). Finally, further actions were taken in partnership with other companies in the industry, so as to increase the sustainability of waste.

The process produces two main kinds of waste: materials used in the manufacturing (plasters moulds, and waste water), and non-conformant products. Non-conformant products are, as much as possible, reprocessed and rebaked during the production. If the product can be repaired, there is an extra energy consumption cost. When repair is not possible, the non-conformant products are disposed in a landfill as inert materials.

Among the other kinds, plaster moulds and clays are treated according to the regulation as non-hazardous waste. For a long period, the unit of analysis disposed them in a landfill, until a recent change in the regulation denied such a possibility. Twelve of the largest companies of the industry, including the one analysed here, consequently joined together in 2010 for the creation of an innovative pilot plant for the total reuse of plasters moulds. Thanks to the cooperation among these business organizations, the waste resulting from the production are concentrated in the plant and transformed into secondary raw materials for the concrete industry.

Clay and waste water are finally treated by the producer itself. The water is purified and reused in the same production process. The clay is disposed in approved storage plants.

The final products are sold to intermediate customers who orient their purchase choices towards factors such as design, quality, price, and brand. The increased sustainability of products and processes are not explicitly considered among their main purchase motivations, but this is an emerging factor that is increasingly redirecting their attention to new market segments. Moreover, some characteristics of more sustainable products turn into cost advantages for the customers-as in the case of reduced consumption of water in use-and might become a differentiation potential for the value delivery to the market.

\subsection{Olive Oil Production Industry}

The second unit of analysis is a firm that produces olive oil, which is an industry connected to the exploitation of local territory and of natural resources (soil, water, agro-forestry, and biological resources). The industry is characterized by the diffused presence of individual producers of small and medium size, and the unit of analysis falls within this category.

The production process is divided into two phases (see Table 2), and makes use of different pressing systems according to the different types of olives to be crushed. Following the crop harvesting in the farm, the olives are transported to a mill where the process takes place. In the first phase of the process the olives are crushed, and the residual fat fraction is extracted both from solid and liquid components.

The production process starts only after a positive conformity and quality check of the olives (origin, freshness, presence of fragments, and absence of mildew). The defoliation step aims at removing leaves and branches for the eventual washing of the olives. The operation is realized through automatic machines, operated by specialized personnel.

The pressing phase makes use of four different systems, chosen according to the different types of olives:

- The traditional method, which makes use of a pressing system for the extraction of the olive oil. This method combines larger outputs with high quality. From an environmental sustainability point of view, the process makes use of a large amount of drinkable water for cleaning needs and produces waste in the form of non-reusable filters that are replaced every year;

- A continuous system that separates oil, water, and pomace through three subsequent phases of decanting. This automatic process reduces production lead time, safeguarding quality at the same time. The process uses warm water which increases the amount of vegetation water that is waste at the end of the cycle; 
- A continuous system composed of two phases, which, compared to the previous one, reduces the presence of waste water. The pomace at the end of this process has high humidity, and cannot be reused as secondary raw material;

- A semi-continuous method based on extraction through percolation. This method is currently less common. It safeguards the quality of the product and reduces the amount of water consumed by the process, thanks to the extraction of the olive oil at room temperature.

Table 2. The olive oil production process.

\begin{tabular}{|c|c|c|c|c|}
\hline & Process Phases & Input & Skills & Output \\
\hline 1. & $\begin{array}{l}\text { Selection, defoliation and } \\
\text { washing of olives }\end{array}$ & $\begin{array}{l}\text { Olives in } \\
\text { certified containers }\end{array}$ & $\begin{array}{l}\text { Agronomist } \\
\text { Machine operators }\end{array}$ & $\begin{array}{l}\text { Olives } \\
\text { Residues } \\
\text { Water }\end{array}$ \\
\hline 2. & Pressing & Olives & $\begin{array}{l}\text { Agronomist } \\
\text { Machine operators }\end{array}$ & Olive paste \\
\hline 3. & Kneading & Olive paste & $\begin{array}{l}\text { Agronomist } \\
\text { Knead processor }\end{array}$ & Olive paste \\
\hline 4. & Traditional extraction & Olive paste & Pressing machine operator & $\begin{array}{l}\text { Crude oil } \\
\text { Water (waste) } \\
\text { Pomace }\end{array}$ \\
\hline 5. & Clarification and filtering & Crude oil & $\begin{array}{l}\text { Agronomist } \\
\text { Oil tasters }\end{array}$ & Filtered oil \\
\hline 6. & Storage and packing & Filtered oil & Storage operator & Packaged/stored oil \\
\hline 7. & Waste products & $\begin{array}{l}\text { Pomace } 35 \% \\
\text { Waste water } 49 \%{ }^{1}\end{array}$ & $\begin{array}{l}\text { Specialized operator } \\
\text { for disposal }\end{array}$ & $\begin{array}{l}\text { Pomace } \\
\text { Water (waste) }\end{array}$ \\
\hline
\end{tabular}

The unit we analysed is a traditional process, which produces high-quality olive oil with exceptional organoleptic properties, avoiding risks of metallic contamination and overheating of the olive paste, which might happen in the other processes.

The process of oil production starts with the olive pressing stage in mechanical mills, which produces a coarse paste (pulp, stone fragments, oil) and granulation when the paste is remixed so as to enable the amalgamation of the oil for the extraction phase. This phase takes place at the controlled temperature of circa $30-35{ }^{\circ} \mathrm{C}$. Technical and scientific specialist personnel monitor this phase to ensure the conditions stay stable, as they heavily influence the quality of the oil and the risk of wasting the product (due to oxidation, or rancidity).

The paste obtained is put into hydraulic presses to separate the liquid (oil and water) from the solid (pomace). The oil is separated by residuals in the purification phase through centrifuges. The final product (virgin olive oil) is stocked in steel containers in the absence of oxygen, to avoid contamination, ready for packaging.

The process has some drawbacks in terms of efficiency due to the high management cost, the use of heavy machinery, and the potential risks of wasting the product if not properly treated. The production process makes use of specialized equipment, and generates waste at all stages: cultivation and harvesting (biomass and pruning residuals), oil extraction (virgin and exhausted pomaces, vegetation waters), and distribution (packaging). Being frequently of small and medium size, producers partner each other in a consortium for the management of mills and of the specialized equipment required by the production process.

The quality of the oil produced is eventually recognized by the customer, and it is the main driver explaining consumption [37].

Residuals and waste from this production process have potential uses in several directions, according to the type of by-product derived from the production. The trimming of plants, and the 
exhausted pomace, can be reused for producing pellets. Residuals of the production process (pomace and residual water) are used in farms as fertilizers and weed killers. The process has opportunities of exchange with other industries to exploit the potential of waste. The chemical potential, in terms of biologically active organic nutrients contained in the residual water, can be used in the cosmetic, food, pharmaceutical, and chemical industry.

Other environmentally sustainable practices of olive production waste disposal are carried out only by large producers, as they require investments that are out of reach for small and medium enterprises (SMEs) like the unit we analysed. In the past, the unit undertook minimal actions on the process design that were mainly oriented to improving the quality of the product, following the stimuli of public funds and incentives.

It must be pointed out that, specifically for this industry, the regulation sets strict limits to the potential uses of waste in the olive oil production processes, specifying mandatory thresholds for input in the environment, taking into account the potential pollutant power that the residual nutrients in the waste water might have. For vegetation water the regulation authorizes transportation out of the mill only for weed killing uses in fields. In general, the regulation is fragmented and bureaucratic, and respecting it imposes further costs to farmers. These rules, together with the average size of producers in the industry, discourage prospected cooperation among business organizations for waste reuse. The waste of the production process has an intrinsic value for the chemical and cosmeceutical industry, as well as for energy production. Cooperation is by matter of fact limited only to the sharing of costly equipment.

\subsection{Wood Transformation Industry}

The third unit of analysis is in the wood processing industry, with a company that works on semi-finished and finished furniture products with a high degree of specialization. The industry has seen a loss of know-how by the increased competition of substitute products, such as panels or laminated timbers. For these reasons, the analysed enterprise has implemented a number of internal changes aimed at shortening the production chain, and introducing innovative and eco-sustainable products with high physical and mechanical performances.

The production process is characterized by first selecting and debarking the product (see Table 3). This step produces a significant quantity of waste composed of cortex, woodchips, and sawdust. The subsequent steps of woodcutting, edge trimming, surface planning, squaring, and shaping aim at giving to the product the intended form based on customers' needs. The wood drying steps enhance wood resistance and rigidity. This phase produces spills of resin and core materials. The selection of sawn timber serves to evidence discrepancies due to the collapse of the wood or the excessive presence of wood fibres, which could generate a warping of the material, and dramatically compromise the quality of the product. Impregnation and painting are carried out using organic antiseptics or paints to enhance wood resistance to atmospheric agents, parasites, larvae or spore. The final phase of the process is the storage of the product in an environment protected from atmospheric agents, to maintain intact the general characteristics of the product.

Innovation in the industry concerns the adoption of modern technologies to improve the design of the product and its quality, measured through physical and mechanical performance parameters.

The customers of the company analysed are intermediate customers (not consumers), and their purchase choices are oriented towards quality, price, and the technical performance of the product.

The potential reuse of waste and by-products is high. Waste is collected by specialized centres, and sent to the processing industries to be recycled. These centres are managed in cooperation by different business organizations through consortia among producers. The centres act concentrating waste products from several producers, and reusing them as secondary raw materials for different processes. These waste products are actually reused as biomass for energy production. The waste produced by this process also has a potential of exploitation at a higher level of value added, allowing for the extraction of nutrients and principles for the cosmeceuticals industry (e.g., for the 
production of tan filters), bio-plastics, or packaging for the food and beverage industry. The widespread dissemination and the small size of the enterprises in the territory make such activity costly, thus limiting the actual possibility to cooperate with other business organizations.

Table 3. The wood processing.

\begin{tabular}{|c|c|c|c|c|}
\hline & Process Phase & Input & Skills & Output \\
\hline 1. & Selection and debarking & Forest wood & Quality control & Selected and measured wood \\
\hline 2. & Sawing and squaring & Selected wood & $\begin{array}{l}\text { Preliminary processing } \\
\text { operator }\end{array}$ & Personalized wood \\
\hline 3. & Drying & Milled/planed wood & Drying operator & Dried wood \\
\hline 4. & Selection of sawn wood & Dried wood & Quality control personnel & $\begin{array}{l}\text { Collapsed or non-conforming wood } \\
\text { Raw wood }\end{array}$ \\
\hline 5. & Processing & Raw wood & $\begin{array}{l}\text { Bending, shaper tools and } \\
\text { operators specialized in the } \\
\text { stages of wood processing }\end{array}$ & Semi-finished wood \\
\hline 6. & Impregnation or coating & Semi-finished wood & Coating operator & Finished wood \\
\hline 7. & Selection & Finished wood & Quality control personnel & $\begin{array}{l}\text { Selected wood } \\
\text { Non-conforming product }\end{array}$ \\
\hline 8. & Storage & Packaged wood & Warehouseman & Stored wood \\
\hline 9. & Packaging & & Warehouseman & Shipping wood \\
\hline 10. & Waste products & & & $\begin{array}{l}30 \% \text { slabs, trims } \\
30 \%-66 \% \text { woodchips } \\
5 \% \text { cortex }\end{array}$ \\
\hline
\end{tabular}

\section{Case Analysis}

The three units of analysis are all characterized by production processes in which the potential to apply circular economy principles for reducing the amount of waste, or for reusing them as secondary raw materials, is high. In the first unit of analysis, the reuse potential inside the production process is high and currently exploited. Also, outside the process the unit shows applications of circular economy principles through the partnering with other business organizations to transform waste into secondary raw materials for a different industry.

Being SMEs, the recycle and reuse of waste of the other two units is limited. The actual cooperation with other business organisations is limited to the simplest forms. In one case (olive oil) this is aimed only at the sharing of costly production equipment, in the other (wood industry), at the usage of waste as raw materials for energy production. The waste produced by these two industries possesses intrinsic characteristics for higher value added exploitations, with high potential areas of cooperation among different business organizations for the collection, concentration, and reuse of waste.

The analysis and discussion of the cases contributed to the identification, across each unit, of factors that both stimulate or dissuade cooperation for the application of circular economy principles (see Table 4).

A first factor concerns the regulation that business organizations are obliged to follow. In all the units we analysed, regulation imposes conditions and sets limits on waste management, which eventually influence waste treatment or potential reuse. As a matter of instance, in the unit of sanitary ceramic, the cooperation emerged to transform non-dangerous waste into secondary raw materials for the construction industry when the regulation denied disposal in the landfill. In the case of the olive oil production, the regulation on vegetation water authorizes transportation out of the production site (the mill) only if it is to be used in farms as weed killer. The regulation is silent on the possibility of transporting vegetation water away from the production site for a different purpose (e.g., for reusing it in a different process), but the way regulation is written seems to imply that other uses are forbidden. The regulations for this industry is extensively detailed, and imposes extra costs to producers for waste treatment. These characteristics, combined with the small size of companies seem 
not to stimulate innovative environmentally friendly praxis, exploiting the potential reuse of waste produced by the production process, either internally or externally. As a matter of fact, cooperation is limited only to sharing the costs of expensive production equipment.

Thus regulation sets the limitations for the application of a circular economy inside or across industries. Regulation identifies legislative constraints limiting and hindering the potential of waste transfer and reuse, especially when these uses are not explicitly considered by the regulation itself. In the presence of several detailed prescriptions, regulation might eventually discourage innovation. When these conditions are met, particularly as in the case of the olive oil production, the application of circular economy principles are absent, or limited.

Table 4. Factors affecting inter-organisational cooperation for circular economy.

\begin{tabular}{|c|c|c|c|}
\hline Factors & Sanitary Ceramic & Edible Oil Crop & Wood Transformation \\
\hline Product innovation & $\begin{array}{l}\text { Drain systems with reduced } \\
\text { water usage }\end{array}$ & & \\
\hline Process innovation & $\begin{array}{l}\text { Automation and control for } \\
\text { reduced waste and defect rates }\end{array}$ & & \\
\hline $\begin{array}{l}\text { Business model } \\
\text { innovation }\end{array}$ & $\begin{array}{l}\text { Production of raw materials } \\
\text { for a different industry } \\
\text { Environmentally sustainable } \\
\text { products during lifetime }\end{array}$ & $\begin{array}{l}\text { Potential production of raw } \\
\text { materials for a different industry }\end{array}$ & $\begin{array}{l}\text { Potential production of } \\
\text { raw materials for } \\
\text { a different industry }\end{array}$ \\
\hline Reduction of resources & $\begin{array}{l}\text { Plastics moulds } \\
\text { Clays } \\
\text { Water }\end{array}$ & Vegetation water & \\
\hline Reuse of waste & $\begin{array}{l}\text { Non-conformant products } \\
\text { Water }\end{array}$ & $\begin{array}{l}\text { Pomace (potential) } \\
\text { Vegetation water (potential) }\end{array}$ & Sawdust \\
\hline Regulation & $\begin{array}{l}\text { Limits for treatment of } \\
\text { non-hazardous waste [38] }\end{array}$ & $\begin{array}{l}\text { Regional limits and authorizations } \\
\text { for agronomic use of vegetation } \\
\text { water, wet pomace, for their } \\
\text { transport and for their use in } \\
\text { farms [39-41] }\end{array}$ & $\begin{array}{l}\text { Limits for treatment of } \\
\text { non-hazardous waste [38] }\end{array}$ \\
\hline $\begin{array}{l}\text { Fiscal and } \\
\text { financial stimuli }\end{array}$ & $\begin{array}{l}\text { Absence of tax relief for } \\
\text { sustainable activities } \\
\text { Access to European Regional } \\
\text { Development Fund (ERDF) } \\
\text { and National funds to support } \\
\text { research and } \\
\text { development investments }\end{array}$ & $\begin{array}{l}\text { Absence of tax relief for } \\
\text { sustainable activities } \\
\text { Access to European Agricultural } \\
\text { Fund for Rural Development } \\
\text { (EAFRD) funds to support the } \\
\text { competitiveness of the industry }\end{array}$ & $\begin{array}{l}\text { Absence of tax relief for } \\
\text { sustainable activities } \\
\text { Access to EAFRD funds to } \\
\text { support the } \\
\text { competitiveness of } \\
\text { the industry }\end{array}$ \\
\hline Consumer behaviour & $\begin{array}{l}\text { Water saving potential } \\
\text { of products } \\
\text { Eco-sustainability } \\
\text { of production }\end{array}$ & Traceability and safety of food & Sustainability of materials \\
\hline $\begin{array}{l}\text { Inter-organisational } \\
\text { cooperation }\end{array}$ & $\begin{array}{l}\text { Production of secondary raw } \\
\text { materials for the } \\
\text { construction industry } \\
\text { New ceramic-based products: } \\
\text { tiles and clay tiles, ceramic } \\
\text { mixtures for sanitary } \\
\text { ware (potential) }\end{array}$ & $\begin{array}{l}\text { Shared equipment } \\
\text { Cooperation for disposal of waste } \\
\text { Reuse of vegetation water as } \\
\text { weed killer } \\
\text { Valorisation of vegetation water } \\
\text { for the production of } \\
\text { cosmeceuticals (potential) } \\
\text { Reuse of pomace as biomass for } \\
\text { energy production (potential) }\end{array}$ & $\begin{array}{l}\text { Cooperating network for } \\
\text { disposing of and reusing } \\
\text { waste (sawdust) } \\
\text { Extraction of active } \\
\text { principles from wood } \\
\text { waste for the } \\
\text { pharmaceutical } \\
\text { industry (potential) }\end{array}$ \\
\hline
\end{tabular}

Fiscal and financial stimuli can be exploited for innovation actions on waste treatment, product, and process redesign. In none of the units analysed were they the main drivers for innovation. Rather, they were an opportunity exploited to pursue the goals of taking actions on the product and process for improved sustainability, or for different actions regarding the product quality.

In terms of possible cooperation with different entities, all the processes analysed show potential points of contacts with other industries, and are in the position to create inter-organisational symbiotic relationships to exploit the valorisation of waste of the process. In the units we analysed, the possibility to improve the effectiveness of internal processes by way of organisational innovation is potentially high, and it is currently exploited in the sanitary ceramic case, mainly by the application of eco-design and waste prevention principles. The actual possibility to exploit further initiatives, also distant from 
the original core business (i.e., producing secondary raw materials for the pharmaceutical industry from the wood production industry) is instead limited. On the one hand, this is due to the lack of a clarity of regulation, which, though not directly, limits innovation, and the absence of specific fiscal or financial stimuli further fail in incentivizing innovation; on the other, this is also due to the absence of a structured network that pursues goals other than scale economies for reducing the pro-quota cost of expensive and specialized production equipment.

A further factor is that of the behaviour of the consumer. Many of the potential advantages deriving from an improved environmental sustainability of products and processes are internal to the business organization. In one case they instead also have effects on the final customer (as in the case of the sanitary ceramic industry). The behaviour of the customer in the three analysed cases is oriented more towards high quality.

All these factors produce potential impacts on the organisational innovation process that, either through product or process redesign, or business model innovation, leads to the reduction of the resources used, to the potential reuse of waste, or enable inter-organisational cooperation.

The sanitary ceramic case, the most complete in this respect, shows that organisational processes were redesigned to reduce the amount of waste, and to increase the capability of reusing waste either within the production process following opportunities offered by the financial and fiscal stimuli. The product was redesigned to reduce the amount of resources (e.g., water) required by customers for its use, to anticipate the increasing demand of more environmental friendly products. Still, in the same case, the innovation in the organisational business model is seen in the introduction of more environmental friendly products, and in the production of raw materials for a different industry. The latter opportunity is exploited through inter-organisational cooperation, and follows a change in the regulation which denied to dispose waste in the landfill. Consequently, the unit of analysis, together with other business organizations, cooperated to produce secondary raw materials for the construction industry.

In the edible oil crop case, however, the complexity of regulation is a potential obstacle which hampers organisational business model innovation. The waste of the oil production process has high potential for exploitation in separate production processes, but the regulation, though not directly denying it, imposes limitations on transport and use of waste that eventually discourage these innovations.

\section{A Meta-Model of the Circular Economy for Inter-Organisational Cooperation}

From the cases analysed, we defined a meta-model of circular economy based on inter-organisational cooperation. The meta-model contains factors, and their relations, which influence the possibilities of business organizations to initiate cooperation aimed at a circular economy. The three main factors we identified as impacting the applications of a circular economy in an inter-organisational perspective are: (i) regulation; (ii) stimuli; and (iii) consumer behaviour.

Regulation comprises the set of laws and norms that business organizations are compulsorily called to abide by. Regulations comes from many different levels (local-regional or municipal—national and international), and can be targeted to a specific industry, waste type, or can be generally applicable. Regulation distinguishes between acceptable and non-acceptable (hence denied) praxis on waste management and reuse. By doing so it plays an ambivalent role in the possibility of stimulating a circular economy. By setting limits to waste treatment that affect reuse, regulation is in the position of fostering innovation by business organizations. At the same time, when regulation is, for instance, complex or fragmented, it could also hamper it.

Complementary to regulation are the potential stimuli that are used as inducements to business organizations, usually by policymakers. These stimuli are in the form of fiscal and financial incentives, targeted respectively to grant tax reliefs or financial contributions to organisational innovation processes that move in the direction of increased environmental sustainability of production and processes. 
Finally, the third factor that impacts on the applications of a circular economy is consumer behaviour. This factor concerns the behavioural choices of consumers that orient their decision whether to buy or not products or services. Consumer behaviour can be influenced by the innovation introduced by the organization, like in the case of environmental sustainable products that have immediate and concrete advantages for the final customer such as reduced energy consumption. Consumer behaviour can also stimulate business organization to move on more environmental sustainable praxis through the demand for more environmentally sustainable products.

These factors are hardly all under the control of business organizations. Only in regard to consumer behaviour are business organizations in the position to be influential. Regulation and stimuli are instead leverages under the control of policymakers, who have the power of setting the ground for cooperation to take place.

These factors impact on organisational innovation. This innovation is of three different types: (i) process; (ii) product; and (iii) business model innovation. Process innovation comprises actions undertaken to redesign the production process to increase its environmental sustainability. This happens through a reduction of resources used (including energy and reduction of waste), or the substitution of resources with less dangerous or more sustainable ones. Product innovation comprises actions undertaken on the design of the product itself to increase its environmental sustainability through the substitution of dangerous materials or pollutants, or to improve the reuse and recycle potential at the end of the product life. Finally, business model innovation refers to the actions undertaken regarding the value delivery to the customer, to exploit innovative environmentally sustainable behaviour, or to partner other business organizations in product and service design and delivery.

Organisational innovation actions lead to increased environmental sustainability in the form of reduced use of resources and reuse of waste. Examples of reduced use of resources are the reduction of energy, of pollutants, and dangerous or hard to recycle materials used in the product design or in the process. Reuse of waste concerns the possibility of finding alternative uses as secondary raw materials either inside the same production process, or in different production processes.

In the end, both the organisational innovation process and the potential reuse of waste enable inter-organisational cooperation for the mutual exchange of resources. The literature uses the concept of inter-organisational symbiosis to describe a form of cooperation among different business organizations in which they partner each other in exchanging resources by setting in place initiatives that lead to the circularity of production processes and industries [42,43]. An inter-organisational symbiosis is that situation in which a business organization is symbiotic with another one or more. These business organizations can work together through the exchange of resources that are of less value if not exchanged, but that acquire value when shared, and targeted to specific uses. Inter-organisational symbiosis is enabled by the possibility of cooperating to reduce resource used, which eventually turns into a reduction of costs, or to reuse waste as secondary raw materials, which creates new business opportunities.

Figure 1 shows the meta-model with the identified factors and their relations among them. We call it "meta-model" as all the concepts depicted in Figure 1 have to be interpreted as classes of real-life entities. Actual models of a circular economy will be composed of specific instances of the identified classes. To give an example, in one of the cases we analysed (olive oil industry) the regulation is composed of several rules at the national and regional level, while in a second one (sanitary ceramic) the regulation affecting the potential application of a circular economy is composed of national, and international norms. Though the specific norms are different, the regulation produces the same kind of effects in the different realities: it distinguishes between acceptable and non-acceptable praxis, and consequently fosters or hampers the reduction of resources and reuse of waste. 


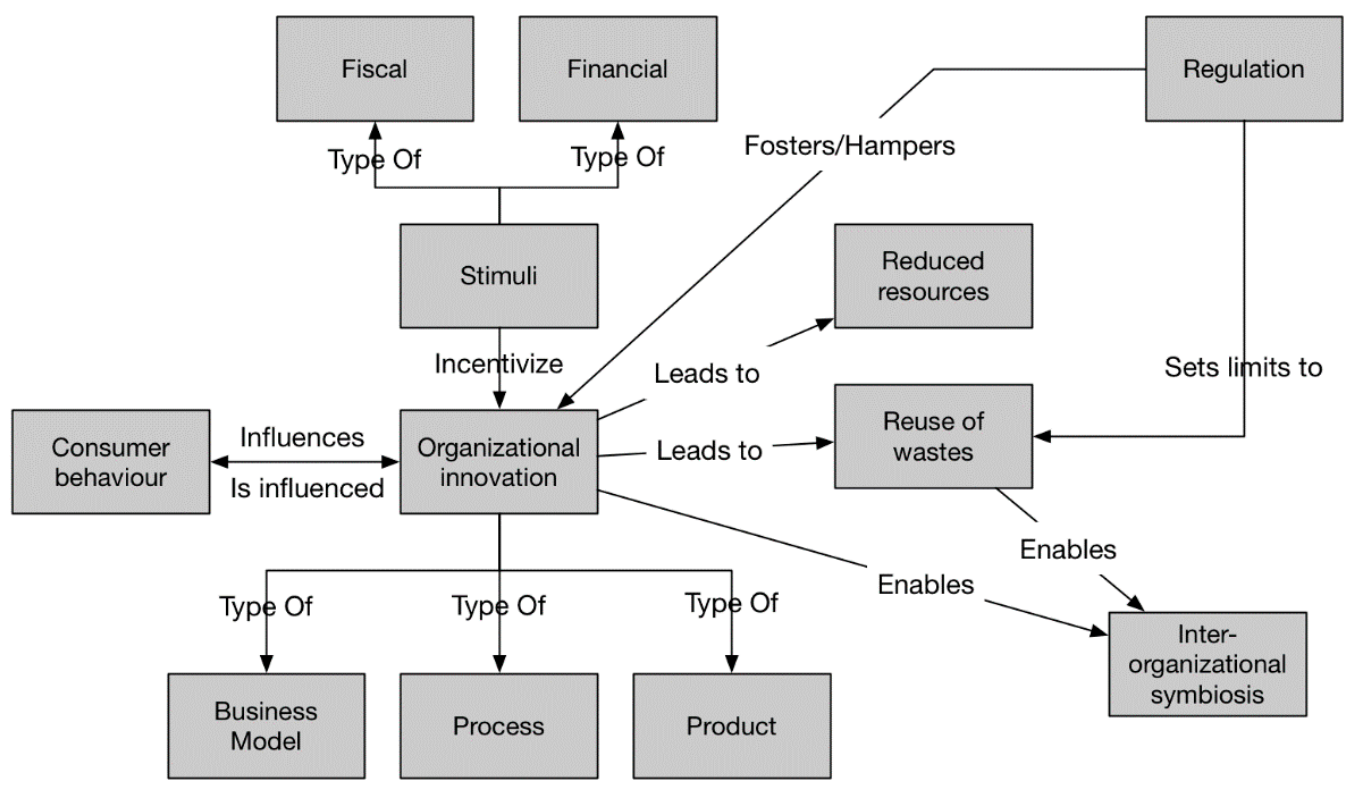

Figure 1. A meta-model of inter-organisational cooperation in a circular economy.

\section{Discussion}

According to the literature, circular economy approaches are either introduced top-down-where the policymakers take the lead in the actions—or bottom-up [10]—where business organizations act first by innovating. The meta-model helps in understanding how these two strategies are interrelated. It identifies the factors involved and shows how business organizations and policymakers' actions interrelate, and eventually impact on inter-organisational cooperation initiatives established through inter-organisational symbiosis.

A relevant aspect of the circular economy is the combined effect of regulation and fiscal and financial stimuli [44]. Several sources in the literature point at the importance of the regulatory framework, mainly as a source of potential barriers against the development of such strategies, or as the result of specific policy action to foster environmental sustainability $[3,26,45-51]$. With regard to the regulation and stimuli, the literature stresses the need for coherence among the different measures in use [52,53], to avoid discouraging innovation initiatives. Such coherence, and such incentive or disincentive potential of regulation and fiscal and financial stimuli, will be evaluated in the light of the consequences they produce on business organization innovation processes.

One strategy used to foster the development of a circular economy is that of the creation of eco-industrial parks where inter-organisational symbiosis among enterprises in the park are emphasized [53-55]. These are settings in which business organizations are concentrated on the basis of the possibilities to reuse resources among them in a circular way. The eco-industrial park is a specialization of industrial parks in which relationships between business organizations are sought to improve competitive advantage $[42,43,51,56]$. On one hand, such a strategy, when pursued for increased environmental sustainability, needs coherence, commitment, and a lack of contradictions by policymakers $[47,57]$. At the same time, it cannot be the only viable strategy to stimulate the development of a circular economy, as it excludes potential cooperation among organizations not within the boundaries of the eco-industrial parks, and also situations in which the concentration of firms in a specifically designed park is not possible.

As for customers' behaviour, studies show that customers are not willing to pay more for cleaner products and services $[57,58]$. The circular economy per se does not necessarily determine an increased cost to the final customer. Indeed circular economy adopters are expected to obtain benefits like cost reduction [8]. The innovation brought by business organizations is also a driver to influence consumers' behaviour by targeting the latter towards more environmentally sustainable paths. 
Finally, regarding the establishment of inter-organisational symbiosis, the literature stresses the need for a mutual competitive advantage between the two subjects entering the symbiosis [56], which normally concerns the exchange of raw materials and by-products [43,51].

\subsection{Implications for Practice and Policymakers}

One implication of our work, for policymakers and for practice, concerns the impact of regulation and of the fiscal and financial stimuli on the development of a circular economy. The literature stresses the need for a coherence of such measures in order to stimulate and not discourage organisational innovation. With regard to the role of the organisational innovation processes, an implication concerns the need to periodically revise the regulatory framework to ensure that the coherence remains even when innovation creates situations that were unknown to policymakers when the regulation was set. It is also important to ensure that the regulation does not discourage innovation, for instance by making alternative uses of waste too complex due to an excess of specificity on waste treatment.

A common strategy for implementing a circular economy is that of the development of eco-industrial parks. The coherence of the regulatory framework shall not be limited only to these settings. Since industrial symbiosis does not only need to be created inside this setting, an implication for policymakers will be to have a regulatory framework that also allows for the establishment of cooperation among individual organizations. Coherence of the regulatory framework across the territory is in this case important as differences of regulation across the territory might impose hurdles to cooperation, which are absent in the case of industrial parks that are usually concentrated in a specific geographical location.

In terms of the role of incentives, the action shall not only be targeted at the recycling of end-of-life resources, but measures supporting cooperation among business organizations (e.g., for joint research and development strategies, for exchange of resources, or other possible scenarios) might also be in the position to stimulate the birth of circular economy initiatives.

Specifically on this, the schema is that of allowing an investment in a specific company to improve the environmental sustainability of a production process. This is normally functional to an improvement of an existing production process. A circular economy can also be fostered through inter-organisational cooperation, and such cooperation might also need a new actor, which has not played a part from the beginning. This might be the case, for instance, when the symbiosis, to be economically sustainable, requires the achievement of a critical mass, and this requires the collection of resources from different business organizations. The implication in this case would be considering the possibility that, following innovation, a new subject enters the stage to make an industrial symbiosis possible, collecting resources from existing entities. This particular case is relevant especially for fiscal and financial stimuli since, if the new subject is not considered eligible for them, this strategy would be impossible.

\subsection{Implications for Research}

The meta-model we propose suggests implications for furthering the study of the adoption of a circular economy. The meta-model identifies the factors that influence the establishment of inter-organisational symbiosis, but much remains to be done from the perspective of the continuity of the symbiosis over time. We would argue for studying the impact of behavioural choices of the different business organizations entering the symbiosis on its long-term survival. In this regard, one area of future research concerns the study of the different communication and coordination mechanisms that make symbiosis stable over time.

Finally, on the establishment of cooperation, we believe that the potential applications of a circular economy do not only stem from the resources that can be exchanged between the organizations willing to cooperate. We hypothesize scenarios in which the existence of a symbiosis is possible only if a third subject plays a role between two organizations, and starts to aggregate and collect waste by business organizations not interested in cooperation. In two out of the four units we analysed 
(olive oil and wood transformation) the waste produced is eligible for other reuses with higher value added than that actually in place. Business organizations show greater interest in economy of scale rather than cooperating in environmental sustainability. At the same time the fragmented regulation (olive oil) discourages alternative uses of waste by the SMEs working in the industry. Under these conditions the only possibility for starting a symbiosis to instil circularity in the industry is through a third party, a subject that is not one of the producers in the industry, that connects detached entities, collecting resources (waste) from them, in order to transform them into secondary raw materials for a different industry. This scenario leaves room for the presence of subjects like brokers, intermediaries or accelerators of cooperation, whose role and effectiveness in the development of a circular economy should be investigated.

At the same time, in a scenario like the one hypothesized, where a new organization is brought into play to enable a cooperation among different actors according to the circular economy paradigm, organisational design choices and inter-organisational coordination mechanism challenges arise. They should be studied in order to find how to better coordinate the action of the network so that every participant in the network has an incentive to contribute, ensuring stability of the cooperation over time, and to avoid freeriding.

\section{Conclusions}

Our work was motivated by the identification of factors impacting on the cooperation among different business organizations for the development of a circular economy. We identified several factors having an impact, and described them and their relations, in a meta-model of a circular economy. The meta-model highlights how the regulatory framework, the fiscal and financial stimuli, and consumer behaviour set the background for organizational innovation, which creates opportunities of cooperation through inter-organisational symbiosis, thanks to the potential reuse of waste and resources, and the reduction of resources used.

Our work contributes to the literature by identifying the factors influencing circular economy when this takes place in an inter-organisational cooperation setting, and can be of support to business organizations aiming to cooperate in a circular economy perspective, or policymakers aiming to stimulate a shift to such a development paradigm.

We have to acknowledge a partial limitation to the work proposed here, since in the empirical analysis we were able to study one existing inter-organisational symbiosis (in the ceramic production case), and we observed and discussed with practitioners the factors potentially explaining the absence of symbiosis in the remaining two cases (olive oil and wood production). Though the prospected cooperation among organizations in the latter two cases are proposals we identified and discussed with practitioners, they do not represent actual and already existing forms of cooperation. For this reason, we suggest targeting future research to further study inter-organisational symbiosis to support circular economy applications among business organizations.

Also, as a consequence of the acknowledge limitation, our work does not currently take into consideration factors in terms of quantity and quality of resources exchanged in the symbiosis, and cannot directly support assessments of economic or technical viability of the potential symbiosis. We strongly believe then that future research can build on the proposed meta-model to address such aspects and to increase the assessment capabilities of potential cooperation in a circular economy paradigm.

Author Contributions: Stefano Poponi, Enrico Maria Mosconi and Alessandro Ruggieri contributed in the collection of data for the cases. All authors contributed for the analysis of the data collected on the cases. Alessio Maria Braccini contributed designing the research process, defining the meta-model and discussing it against the literature. All the authors contributed to the formulation of implications for research and for practice, and all authors approved the manuscript.

Conflicts of Interest: The authors declare no conflict of interest. 


\section{References and Notes}

1. Dyllick, T.; Hockerts, K. Beyond the business case for corporate sustainability. Bus. Strategy Environ. 2002, 11, 130-141. [CrossRef]

2. Kurnia, S.; Mahbubur, R.M.D.; Gloet, M. Understanding the roles of IS/IT in sustainable supply chain management. In Proceedings of the Pacific Asia Conference on Information Systems (PACIS 2012), Ho Chi Minh City, Vietnam, 11-15 July 2012.

3. MacArthur, E. Towards the Circular Economy: Accelerating the Scale-up across Global Supply Chains. Technical Report, World Economic Forum. 2014. Available online: https:/ /www.weforum.org/reports / towards-circular-economy-accelerating-scale-across-global-supply-chains/ (accessed on 15 January 2016).

4. Yuan, Z.; Bi, J.; Yuichi, M. The circular economy: A new development strategy in China. J. Ind. Ecol. 2014, 10, 4-8. [CrossRef]

5. Kopnina, H. Consumption, waste and (un)sustainable development: Reflections on the Dutch holiday of Queen's day. Environ. Syst. Decis. 2014, 34, 312-322. [CrossRef]

6. Baines, T.S.; Lightfoot, H.W.; Evans, S.; Neely, A.; Greenough, R.; Peppard, J.; Roy, R.; Shehab, E.; Braganza, A.; Tiwari, A.; et al. State-of-the-art in product-service systems. J. Eng. Manuf. 2007, 221, 1543-1552. [CrossRef]

7. Li, M.S.; Zang, H.M.; Li, Z.; Tong, L.J. Economy-wide material input/output and dematerialization analysis of Jilin Province (China). Environ. Monit. Assess. 2010, 165, 263-274. [CrossRef] [PubMed]

8. Mittermeyer, S.A.; Njuguna, J.A.; Alcock, J.R. Product-service systems in health care: Case study of a drug-device combination. Int. J. Adv. Manuf. Technol. 2010, 52, 1209-1221. [CrossRef]

9. MacArthur, E. Delivering the Circular Economy: A Toolkit for Policymakers. 2015. Available online: https://www.ellenmacarthurfoundation.org/publications (accessed on 15 January 2016).

10. Lieder, M.; Rashid, A. Towards circular economy implementation: A comprehensive review in context of manufacturing industry. J. Clean. Prod. 2015, 115, 36-51. [CrossRef]

11. Beuren, F.H.; Gomes Ferreira, M.G.; Cauchick Miguel, P.A. Product-service systems: A literature review on integrated products and services. J. Clean. Prod. 2013, 47, 222-231. [CrossRef]

12. Mont, O.; Tukker, A. Product-service systems: Reviewing achievements and refining the research agenda. J. Clean. Prod. 2006, 14, 1451-1454. [CrossRef]

13. Tukker, A. Product services for a resource-efficient and circular economy-A review. J. Clean. Prod. 2013, 97, 76-91. [CrossRef]

14. Leimeister, J.M.; Glauner, C. Hybride Produkte enordunung und her-ausforderungen für die wirtschaftsinformatik. Wirtschaftsinformatik 2008, 50, 248-251. [CrossRef]

15. Schulte, U.G. New business models for a radical change in resource efficiency. Environ. Innov. Soc. Transit. 2012, 9, 43-47. [CrossRef]

16. Sevigné-Itoiz, E.; Gasol, C.M.; Rieradevall, J.; Gabarrell, X. Environmental consequences of recycling aluminum old scrap in a global market. Resour. Conserv. Recycl. 2014, 89, 94-103. [CrossRef]

17. Wen, C.F.; Zhao, Y.L.; Liang, R.Z. Recycle of low chemical potential substance. Resour. Conserv. Recycl. 2007, 51, 475-486. [CrossRef]

18. Zhao, Y.; Zang, L.; Li, Z.; Qin, J. Discussion on the model of mining circular economy. Energy Procedia 2012, 16, 438-443. [CrossRef]

19. Blériot, J. No Chapter I-“Good Rather Than Less Bad: The Circular Approach”. 2012. Available online: http:/ / www.ellenmacarthurfoundation.org/circular-economy / /good-rather-than-less-bad-thecircular-approach (accessed on 15 Mach 2013).

20. European Union. Circular Economy Strategy. Available online: http:/ /ec.europa.eu/environment/circulareconomy/index_en.htm (accessed on 5 February 2014).

21. Kurilova-Palisaitiene, J.; Lindkvist, L.; Sundin, E. Towards facilitating circular product life-cycle information flow via remanufacturing. In Proceedings of the the 22nd CIRP Conference on Life Cycle Engineering, Sydney, Australia, 7-9 April 2015; pp. 780-785.

22. Park, J.; Sarkis, J.; Wu, Z. Creating integrated business and environmental value within the context of China's circular economy and ecological modernization. J. Clean. Prod. 2010, 18, 1494-1501. [CrossRef]

23. Smol, M.; Kulczycka, J.; Henclik, A.; Gorazda, K.; Wzorek, Z. The possible use of sewage sludge ash (SSA) in the construction industry as a way towards a circular economy. J. Clean. Prod. 2015, 95, 45-54. [CrossRef] 
24. Clark, G.; Kosoris, J.; Hong, L.N.; Crul, M. Design for sustainability: Current trends in sustainable product design and development. Sustainability 2009, 1, 409-424. [CrossRef]

25. Behrisch, J.; Ramirez, M.; Giurco, D. Representation of Ecodesign Practice: International Comparison of Industrial Design Consultancies. Sustainability 2011, 3, 1778-1791. [CrossRef]

26. Dong, L.; Zhang, H.; Fujita, T.; Ohnishi, S.; Li, H.; Fujii, M.; Dong, H. Environmental and economic gains of industrial symbiosis for Chinese iron/steel industry: Kawasaki's experience and practice in Liuzhou and Jinan. J. Clean. Prod. 2013, 59, 226-238. [CrossRef]

27. Tukker, A.; Tischner, U. Product-services as a research field: Past, present and future. Reflections from a decade of research. J. Clean. Prod. 2006, 14, 1552-1556. [CrossRef]

28. Frey, M. La green economy come nuovo modello di sviluppo. ImpresaProgetto. Electron. J. Manag. 2013, 3, 1-18.

29. Normann, R.; Ramirez, R. From value chain to value constellation: Designing interactive strategy. Harv. Bus. Rev. 1993, 71, 65-77. [PubMed]

30. Stabel, C.B.; Fjeldstad, Ø.D. Configuring value for competitive advantage: On chains, shops and networks. Strateg. Manag. J. 1998, 19, 413-437. [CrossRef]

31. Yin, R.K. Case Study Research: Design and Methods; Sage Publicaitons: Thousand Oaks, CA, USA, 2009.

32. Cavaye, A.L.M. Case Study Research: A Multi-Faceted Research Approach for IS. Inf. Syst. J. 1996, 6, $227-242$. [CrossRef]

33. Eisenhardt, K.M. Building Theories from Case Study Research. Acad. Manag. Rev. 1989, 4, 532-550.

34. Federici, T.; Braccini, A.M.; Sæbø, Ø. Gentlemen, all aboard! ICT and party politics: Reflections from a Mass-eParticipation experience. Gov. Inf. Q. 2015, 32, 287-298. [CrossRef]

35. Kuznetsova, E.; Zio, E.; Farel, R. A methodological framework for Eco-Industrial Park design and optimization. J. Clean. Prod. 2015, 126, 308-324. [CrossRef]

36. Scheel, C. Beyond Sustainability. Transforming industrial zero-valued residues into increasing economic returns. J. Clean. Prod. 2016, 131, 376-386. [CrossRef]

37. De Santis, D.; Ruggieri, A.; Silvestri, C.; Poponi, S. Extra virgin olive oil quality and consumer perceptions: A case study. In Innovazione, Sostenibilità e Tutela Dei Consumatori: L'evoluzione Della Scienze Merceologiche per la Creazione di Valore e Competitività, Proceedings of the XXVI National Congress of Commodity Sciences, Pisa, Italy, 13-15 February 2014.

38. Identification of Non-Hazardous Waste Subject to Simplified Recovery Procedures under Articles 31 and 33 of Legislative Decree 5 febbraio 1997. Law 22/1998, as amended, 1998.

39. New Rules on Agricultural Use of Waste Water and Waste from Oil Mills. Law 574/1996, 1996.

40. General Criteria and Technical Standards for Regional Governing the Use of Agricultural Waste Water and Discharges from Oil Mills, under Article 38 of Legislative Decree of 11 May 1999, Decree of the Italian Ministery of Agriculture and Forestry, 6 July 2005.

41. Regional Legislation on the Action Program for Vulnerable Zones by Nitrates from Agricultural Sources and Agronomic Use of Animal Manure, the Waste Water from Oil Mills and Certain Wastewater. Regional Law Number 17/2006, 2006.

42. Chertow, M.R. Industrial symbiosis: Literature and taxonomy. Ann. Rev. Energy Environ. 2000, 25, 313-337. [CrossRef]

43. Chertow, M.R. Uncovering industrial symbiosis. J. Ind. Ecol. 2007, 11, 11-30. [CrossRef]

44. Chang, I.-S.; Zhao, J.; Yin, X.; Wu, J.; Jia, Z.; Wang, L. Comprehensive utilizations of biogas in Inner Mongolia, China. Renew. Sustain. Energy Rev. 2011, 15, 1442-1453. [CrossRef]

45. Zhang, J.-H.; Chen, M. Assessing the impact of China's vehicle emission standards on diesel engine remanufacturing. J. Clean. Prod. 2015, 107, 177-184. [CrossRef]

46. Yu, C.; de Jong, M.; Dijkema, G.P.J. Process analysis of eco-industrial park development-The case of Tianjin, China. J. Clean. Prod. 2014, 64, 464-477. [CrossRef]

47. Wübbeke, J.; Heroth, T. Challenges and political solutions for steel recycling in China. Resour. Conserv. Recycl. 2014, 87, 1-7. [CrossRef]

48. Xue, B.; Chen, X.P.; Geng, Y.; Guo, X.J.; Lu, C.P.; Zhang, Z.L.; Lu, C.Y. Survey of officials' awareness on circular economy development in China: Based on municipal and county level. Resour. Conserv. Recycl. 2010, 54, 1296-1302. [CrossRef]

49. Geng, Y.; Fu, J.; Sarkis, J.; Xue, B. Towards a national circular economy indicator system in China: An evaluation and critical analysis. J. Clean. Prod. 2012, 23, 216-224. [CrossRef] 
50. Zhang, T.; Chu, J.; Wang, X.; Liu, X.; Cui, P. Development pattern and enhancing system of automotive components remanufacturing industry in China. Resour. Conserv. Recycl. 2011, 55, 613-622. [CrossRef]

51. Yu, F.; Han, F.; Cui, Z. Evolution of industrial symbiosis in an eco-industrial park in China. J. Clean. Prod. 2015, 87, 339-347. [CrossRef]

52. Matus, K.J.M.; Xiao, X.; Zimmerman, J.B. Green chemistry and green engineering in China: Drivers, policies and barriers to innovation. J. Clean. Prod. 2012, 32, 193-203. [CrossRef]

53. Gabriela-Cornelia, P.; Iudith, I.; Alexandru, B. New Theoretical and Practical Approaches of Implementing the Circular Economy for the Preservation of Natural Resources. Procedia Econ. Financ. 2015, 22, 124-130. [CrossRef]

54. Mathews, J.A. Naturalizing capitalism: The next Great Transformation. Futures 2011, 43, 868-879. [CrossRef]

55. Park, J.Y.; Chertow, M.R. Establishing and testing the "reuse potential" indicator for managing wastes as resources. J. Environ. Manag. 2014, 137, 45-53. [CrossRef] [PubMed]

56. Bain, A.; Shenoy, M.; Ashton, W.; Chertow, M. Industrial symbiosis and waste recovery in an Indian industrial area. Resour. Conserv. Recycl. 2010, 54, 1278-1287. [CrossRef]

57. Liu, Y.; Bai, Y. An exploration of firms' awareness and behavior of developing circular economy: An empirical research in China. Resour. Conserv. Recycl. 2014, 87, 145-152. [CrossRef]

58. Liu, Q.; Li, H.; Zuo, X.; Zhang, F.; Wang, L. A survey and analysis on public awareness and performance for promoting circular economy in China: A case study from Tianjin. J. Clean. Prod. 2009, 17, 265-270. [CrossRef]

(C) 2016 by the authors; licensee MDPI, Basel, Switzerland. This article is an open access article distributed under the terms and conditions of the Creative Commons Attribution (CC-BY) license (http:/ / creativecommons.org/licenses/by/4.0/). 